\title{
Rationale for nutrition-oriented epidemiological study of breast cancer in Indonesia
}

\author{
Yoshiyuki Ohno*, Santoso Cornain\#
}

\begin{abstract}
Abstrak
Penelitian kerjasama Jepang-Indonesia tentang Etiologi dan Klinikopatologi pada Kanker Payudara, yang secara resmi dimulai pada tahun 1989, diperpanjang pada tahun 1992 sebagai Penelitian Kerjasana Jepang-Indonesia tentang Epidemiologi Gizi pada Kanker Payudara. Dalam makalah ini, dasar penikiran untuk perpanjangan dan penyelenggaraan telaah epidemiologi dari segi gizi pada kanker payudara di populasi wanita Indonesia dibicarakan dalam kaitan dengan penemuan-penemuan gizi yang dihasilkan oleh penelitian kasus-kontrol tahap pertama di Jakarla pala tahun. 1989-1991. dan berdasarkan makna faktor gizi sebagai faktor risiko kanker yang sekarang diketahui secara pasti dari banyak penelitian epidemiologik di dunia. Akhirnya, diuraikan pedoman-pedoman dari segi gizi yang kini dianjurkan sebagai pencegahan terjadinya penyakit yang terutana ditemukan pada orang dewasa, seperti kanker dan penyakit kardiovaskuler di antara masyarakat Jepang. Ditekankan perlunya perumusan pedoman-pedoman yang khas untuk golongan etnik Indonesia untuk menurunkan angka kejadian kanker di Indonesia.
\end{abstract}

\begin{abstract}
Japan-Indonesia Joint Study on Etiology and Clinicopathology of Breast Cancer, which officially started in 1989, was extended in 1992 as Japan-Indonesia Joint Study on Nutritional Epideniology of Breast Cancer: In Ihis paper; the rationale for extending and conducting a nutrition-oriented epidemiological study of breast cancer in Indonesia female population was discussed in the light of dietary findings that emerged from a case-control study of our first-batch studies conducted at Jakarta in 1989-1991, and of the dietary risk factors for cancer; which were now well-established and known from numerous epidemiological investigations in the world. Finally, the dietary guidelines now suggested for preventing the occurrence of such major maladies in adulthood as cancers and cardio- and cerebro-vascular diseases among Japanese population, were described, emphasizing the necessity of formulating Indonesianvethnic-specific dietary guidelines for reducing cancer incidence in Indonesia.
\end{abstract}

Keywords: Japan, Indonesia, breast cancer, nutrition, dietary guidelines, epidemiology

\section{INTRODUCTION}

Japan-Indonesia Joint-Study on Etiology and Clinicopathology of Breast Cancer, which was extended in 1992 as Japan-Indonesia Joint Study on Nutritional Epidemiology of Breast Cancer, had been undertaken at Jakarta, with the large financial supports from Ministry of Education, Science, Sports and Culture of Japanese Government (Grant No. 01042007, 04042013 and 06042006) and with a partial support from the Indonesian Cancer Foundation.

This collaborative study officially started in 1989, after the 2 years preparation period, and had lasted to 1995. The major scientific background for initiating

\footnotetext{
* Department of Preventive Medicine, School of Medicine. Nagoya University, Nagoya 466, Japan

* Department of Anatomic Pathology. Faculty of Medicine, University of Indonesia, Jakarta 10430, Indonesia
}

this collaboration and its chronological developments of the project were described elsewherel).

In this communication, the authors will describe and discuss the rationale and necessity for conducting a nutrition-oriented epidemiological study of breast cancer in Indonesian female population, based on several dietary findings that emerged from a casecontrol study of our first-batch studies conducted in 1989-1991, and also will show the dietary risk and protective factors for cancer of major sites, including breast cancer, by summarizing numerous dietary epidemiological studies undertaken so far in the world. The authors will finally present the dietary guidelines, which are now suggested for preventing the occurrence of such major maladies in adulthood as cancer and cardio- and cerebro-vascular diseases among Japanese population, emphasizing in particular the scientific contribution of our collaborative studies to formulating Indonesian or ethnic-specific dietary/life-style guidelines for reducing cancer incidence in Indonesia. 
Table 1. Possible/actual ways of means whereby diet can affect cancer incidence

1. Carcinogens are contained in natural foodstuffs (plant products)

Example : Blacken fern, Clotsfoot, Dandelion, Cycad, etc.

Most of them are considered of low carcinogenecity when consumed in usual amounts.

2. Grains (e.g., peanuts and corn) harvested in the hot and humid regions in some countries are possibly contaminated with carcinogenic mycotoxins (e.g. Aflatoxin B1)

3. Some food additives (e.g., AF2 and butter yellow) are known to be mutagenic and carcinogenic, though such activities were banned for use.

4. Mutagens and carcinogens are produced on cooking, particularly when heating.

Example : Trp-p-1, Trp-p-2, Glu-p-1, Glu-p-2, MeIQx, etc.

5. Carcinogens are produced in the body (e.g., in gastrointestinal tract) from food constituents (e.g., nitrates, nitrites, secondary amines).

Example : Nitrosamines are formed in the mouth or stomach, when nitrites (contained in the saliva and foods or produced

by reduction of nitrates contained in pickled vegetables or some other foods) react with the low grade amines

6. Diet rich in fat and poor in fiber is considered to enhance colorectal cancer risk, and so does concentrated salt for stomach cancer risk.

7. Indirect effects of under/mal-nutrition.

Possibly by increasing susceptibility to virus infection, including oncogenic virus infection.

8. Indirect effects of over-nutrition

Possibly by promoting cancer growth, changing the age at menarche, or by adipose-tissue-derived estrogen, etc.

9. Foodstuffs rich in Vitamin A, -carotene and Vitamin C have inhibitory effects for carcinogenesis.

\section{Major dietary findings found in a case-control study conducted at jakarta in 1989-1991}

Research efforts for past several decades have clearly provided evidence, which strongly suggests the importance of life-style or environmental modifications for the risk of certain cancers. Among such modifications, dietary ones have been most extensively studied, and possible/actual ways or means whereby diet can affect cancer incidence have been suggested 2,3 as shown in Table 1, though the underlying biochemical mechanism are not yet fully known.

Life-style or environmental factors other than diet have also been suggested to be significantly related to breast cancer such as smoking and drinking habits, obesity, reproductive episodes (menarche, pregnancy, child birth, breast feeding, menopause), contraceptive use, family history of breast diseases, and so forth 4 . Since these factors suggested are all detected by epidemiological investigations conducted mostly in the well-developed countries, then it is of essential importance to examine whether they are applicable to Indonesian females whose breast cancer is the second most common malignancy following cervical cancer. 5,6 Based on this scientific interest, we initiated a joint study on breast cancer at Jakarta with three-fold approaches, i.e., epidemiological, clinical and pathological.
As an epidemiological investigation, a case-control study was adopted in order to explore Indonesianspecific risk factors for female breast cancer. In this case-control study, we designed and recruited 300 cases and 600 controls $^{7}$ as defined below. Eligible cases were all hospitalized and ambulatory female patients with primary breast cancer, irrespective of its clinical stage, histopathologically confirmed and newly diagnosed at the Department of Surgery, Dr. Cipto Mangunkusumo National Central General Hospital, University of Indonesia, Jakarta for 3 years, from November 1988 to December 1991. Only incident cases aged 25-79 years were included, and those with other malignancy were excluded. Controls were female patients with disease other than cancer and without breast lumps, admitted to or visited the same department. Controls were individually matched to the cases for such variables as sex (female), age ( \pm 3 years), socio-economic level (type of hospital room used or intended to use), and date of admittance or visit ( \pm 3 months). Controls were collected twice as many as cases.

Epidemiological information were collected by direct interview of the study subjects themselves by two well-trained nurses of Division of Surgical Oncology, using a standardized questionnaire, ${ }^{8}$ which included routine demographic data, educational attainment, ages 
Table 2. Dietary factors associated with cancer occurrence by site

\begin{tabular}{|c|c|c|c|}
\hline \multirow[t]{2}{*}{ Cancer site } & \multicolumn{2}{|c|}{ Dietary risk Factors } & \multirow{2}{*}{$\begin{array}{l}\text { Other risk factors } \\
\text { (Enhancing) }\end{array}$} \\
\hline & Enhancing & Reducing & \\
\hline Oral cavity \& Pharynx & Alcohol & green/yellow vegetables & $\begin{array}{l}\text { smoking, tobacco chewing, } \\
\text { bittel chewing }\end{array}$ \\
\hline Esophagus & $\begin{array}{l}\text { Alcohol, tea gruel, deficiency of } \\
\text { iron, vit. A and protein, too hot } \\
\text { foodstuffs and drinks, tannin }\end{array}$ & $\begin{array}{l}\text { green/yellow vegetables, } \\
\text { fruits, protein-vitamin- } \\
\text { mineral rich diet, }\end{array}$ & smoking \\
\hline Stomach & $\begin{array}{l}\text { Salty foodstuffs, salted and dried } \\
\text { fishes, overintake of rice, too hot } \\
\text { foodstuffs and drinks, } \\
\text { irregular-eating habit }\end{array}$ & $\begin{array}{l}\text { green/yellow vegetables, } \\
\text { fruits, milk \& milk } \\
\text { products, miso soup (?) }\end{array}$ & smoking \\
\hline Colon & $\begin{array}{l}\text { High-fat diet, low-fiber diet, } \\
\text { beer (rectum), } \\
\text { hypocholerterolemia (?) }\end{array}$ & $\begin{array}{l}\text { fiber-rich diet, } \\
\text { protein-rich diet }\end{array}$ & inactive physical activities \\
\hline Liver & $\begin{array}{l}\text { Alcohol, aflatoxin B } 1 \\
\text { undernutrition }\end{array}$ & & $\begin{array}{l}\text { viral infection, Schistosomiasis } \\
\text { Japonica }\end{array}$ \\
\hline Pancreas & High-fat diet, coffee (?) & & smoking \\
\hline Lung & High-intake of cholesterol (?) & $\begin{array}{l}\text { green/yellow vegetables, } \\
\text { (Vit. A, } \beta \text {-carotene) }\end{array}$ & $\begin{array}{l}\text { smoking, air pollution, asbestos, } \\
\text { uranium, chromium, beryllium, } \\
\text { arzenic }\end{array}$ \\
\hline 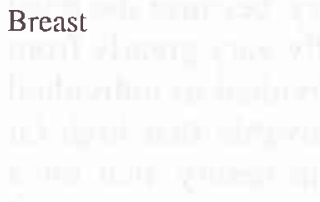 & High-fat diet, high-calorie diet & green/yellow vegetables & $\begin{array}{l}\text { early menarche, late menopause, } \\
\text { unmarried, obesity, late first-birth, } \\
\text { few child bearing, family history } \\
\text { of breast cancer (mother and sisters) } \\
\text { and benign breast diseases }\end{array}$ \\
\hline Cervix uteri & Deficiency of Vit. A & & $\begin{array}{l}\text { early marriage, many deliveries, } \\
\text { multiple sex partners, prostitution, } \\
\text { viral infection (Herpes II, HPV), } \\
\text { smoking (?) }\end{array}$ \\
\hline Corpus uteri & High-fat diet (?) & & estrogen pills \\
\hline Ovary & High-fat diet (?) & & \\
\hline Prostate & High-fat diet (?) & $\begin{array}{l}\text { green/yellow vegetables } \\
\text { ( } \beta \text {-carotene) }\end{array}$ & $\begin{array}{l}\text { cadmium, married, fertile, multiple } \\
\text { sex partners, frequent coitus, } \\
\text { delayed sexual drive, STD history }\end{array}$ \\
\hline Kidney & High-protein diet (?) & & smoking \\
\hline Urinary bladder & & green/yellow vegetables & $\begin{array}{l}\text { smoking, exposure to aniline } \\
\text { pigment, Schistosoma } \\
\text { Haematobium infection }\end{array}$ \\
\hline
\end{tabular}

(at menarche, first intercourse, first marriage, and menopause), breast trauma, reproductive episodes, menstruation status at each decade, breast feeding, exposures to hormonal contraceptives and radiation, family history of cancers and dietary practices as in- take frequency of selected foods and drinks. A series of logistic regression analysis which controlled potentially confounded variables disclosed many significant risk enhancing/protective factors for Indonesian female breast cancer. ${ }^{7,9}$ 
Among dietary practices which were questioned by intake frequency of 5 categories (almost daily, 3-4 times/week, 1-2 times/week, less than once a week and almost never taken), daily consumers of milk and fatty meats, for example, significantly increased the risk and so did frequent intake of fresh fruits. Coconut milk food was also related with an increased risk, when taken frequently among post-menopausal women. In contrast, daily eaters of cooked vegetables experienced a significantly reduced risk of breast cancer. ${ }^{9}$

In short, these dietary findings detected by the casecontrol study essentially indicated an important contribution of diet itself to female breast cancer carcinogenesis in Indonesia as well. And since these results also rationalized to conduct further epidemiological study which would examine in details, responsible nutrients in foodstuffs, we then decided in 1991 to undertake the second case-control study with the same scheme of identifying 200 cases and 400 controls from February 1992 to September 1995. For this purpose, we recruited a few nutritionists who directly interviewed the study subjects. Meanwhile, we had developed a standardized questionnaire ${ }^{10}$ after several pre-tests and revisions, 11,12 which could obtain reliable and reproducible nutritional data for calculating macro- and micro- nutrients consumed before and after marriage, using Indonesian and South East Asian Food Conversion Tables.

The readers would be able to find the major findings obtained from this nutrition-oriented case-control study in the following papers in this monograph.

\section{Dietary risk and protective factors for major can- cers}

In conjunction with several dietary factors disclosed by the first case-control study and those to be ex- plored by the second case-control study at Jakarta, dietary factors and nutrients in diet now ubiquitously recoqnized to enhance or reduce the risk of cancer are summarized by site in Table 2 , based on numerous epidemiological investigations performed in the welldeveloped countries, together with well-established non-dietary risk-enhancing factors. ${ }^{13}$

In Table 2, at a glance, green/yellow vegetables are protectively associated with cancer of seven sites, whereas high fat diet definitely or suggestively with an increased risk of six cancer sites. Large ingestion of green/yellow vegetables may not exert any serious health hazards and , therefore, are believed to be recommendable for everyone as one of primary preventive measures common to cancer. A biomedical ingredient, beta-carotene, which is much contained in green/yellow vegetables, might reduce cancer risk as a result of its conversion to retinol, which is involved in the regulation of cell differentiation and has been experimentally shown to inhibit carcinogenesis, or through its action as an antioxidant and free radical scavenger. ${ }^{14}$ It seems also to be recommendable to avoid high-fat diet, but not commonly to all countries and not to everyone in one country, because the level of fat consumption does apparently vary greatly from country to country, and from individual to individual in one country. It is quite conceivable that high-fat diet in one country is the diet, in reality, that most persons cannot afford to eat in another country, and low-fat diet in one country is already high-fat diet in another country. Adequate dietary amount of daily fat consumption should be correctly recommended for each individual by nutritional analysis personally performed; reduction (increase) to adequate amount for those with too much fat intake (those with short intake), that is daily amount of fat to be consumed should be, it self more cautiously indicated on individual basis. In order to fulfil this, chronological investigations of current country/area-specific average

Table 3. Dietary guidelines for primary prevention of cancer in Japan

1. Avoid highly-salted foodstuffs

2. Avoid overintake of fat and total caloric

3. Intend to take vegetables (green/yellow \& fresh vegetables in particular) and fruits, which contain much carotenes and vitamin $\mathrm{C}$

4. Intend to take such fiber-rich foodstuffs often as unrefined grains, vegetables, beans, mushrooms and seaweed

5. Avoid over-drinking of alcoholic beverage

6. Avoid too hot drinks and foodstuffs

7. Avoid ill-balanced dietary practise and repeated intake of the same foodstuffs, that is take many kinds of foodstuffs well-balancedly

8. Take meals regularly and chew well. 
Table 4. Dietary guidelines for primary prevention of chronic diseases in adulthood in Japan

1. Intend to take more than 30 kinds of food-materials a day

2. Take soybean products or fishes once a day

3. Take green/yellow vegetables at least once a day

4. Intend to take milk and/or milk product

5. Take meats and fishes with a ratio of $1: 1$

6. Use vegetable oils, when preparing oil-cooked dishes

7. Avoid foodstuffs which contain too much sugar'

8. Intend to take less foodstuffs which contain too much salt

9. To reduce salt intake, try to cook foodstuffs with other seasonings such as pepper, garlic and vinegar

10. Alcoholic beverages should be taken moderately [up to 2 Goes ( 50 grams of alcohol) a day.

amount of daily fat consumption should, at least, be disclosed by well-designed national nutrition survey, together with country/area specific daily nutrient allowance and its adequate amount, which will not enhance the risk of cancer and other chronic diseases in adulthood. Based on these national/area-specific figures and actual nutrient intakes to be calculated by personal nutritional analysis, recommendable daily amounts of fat and other nutrients are to be decided for each individual.

Dietary guidelines for primary prevention of cancer and chronic diseases in adulthood in Japan

In Japan, dietary guidelines 15 were proposed by the Ad hoc Committees for the primary prevention of cancers and chronic diseases in adulthood by the thorough review of dietary findings disclosed by numerous epidemiological investigations conducted mostly in the developed countries and Japan, and also by referring to traditional dietary habits and dietary changes/practices among Japanese population.

Table 3 in the guidelines for cancers, and Table 4 for such chronic diseases in adulthood as cardio- and cerebro-vascular diseases and cancers. The guidelines are all quite common sense, but usually hard to be complied without the strong self-imposed will.

These guidelines are applicable and recommendable for Japanese in Japan, i.e., Japanese-specific. This does essentially imply that different dietary guidelines should be prepared for different countries or different ethnic groups (particularly in Indonesia), based on genuine findings from country/ethnic-specific epidemiological investigations likewise our collaborative study, since each country or ethnic group has its own life-styles and dietary habits/practices as a part of its own culture and tradition. In this meaning, therefore, our nutrition-oriented epidemiological study of breast cancer are deemed to be quite rationale with large scientific contributions to Indonesian investigators.

Finally, highly hoped is a series of Indonesian/ethnicspecific epidemiological studies by Indonesian investigators, which aim at exploring probable association between diet and major maladies in adulthood in Indonesia. This is inevitably required not to propose misdirected dietary guidelines, which may be often be prepared by simply adopting the findings detected in the countries other than Indonesia.

\section{Acknowledgments}

We are highly grateful to all investigators and interviewers who were involved in this collaborative study with great enthusiasm, Japanese Government and Indonesian Cancer Foundation who had provided long-term financial supports.

\section{REFERENCES}

1. Ohno Y. Initiation of the International collaborative study on breast cancer between Japan and Indonesia. Med J Indon 1995; 4: 131-4.

2. Miller AB. Nutrition and cancer. Prev Med 1980; 9: 186-96

3. Tominaga S, Kato I. Diet, nutrition and cancer in Japan. NutrHealth 1992; 8: 125-32.

4. Vorherr H. Breast cancer: Epidemiology, endocrinology, biochemistry and pathology. Urban \& Schwarzenberg, Inc., Baltimore Munich, 1980.

5. Cornain S, Mangunkusumo R, Nasar IM, Prihartono J. Ten most frequent cancers in Indonesia: Pathology based cancer registry data of 1988-1989. In: Cancer Registry in Indonesia. National Registry Centre, Jakarta Coordinating Board, 1990. 
6. Prihartono J, Mangunkusumo R, Partoatmojo P. Establishing pathology based cancer registry: Indonesian experience. In : Sasaki R, Aoki K, editors. Epidemiology and Prevention of Cancer. Proceedings of Monbusho (Ministry of Education, Science and Culture) International Symposium on Comparative Study of Etiology \& Prevention of Cancer, Nagoya, 1989. Nagoya: University of Nagoya Press, 1990: $211-6$.

7. Budiningsih S, Ohno Y, Prihartono J, Ramli M, Wakai K, Cornain S, et al. Epidemiological analysis of risk factors for breast cancer in Indonesian females. Med J Indon 1995; 4: 163-8.

8. Cornain S. Planning, organizing and management of the collaborative project on breast cancer, Appendix A. 1995; 4: 191-6.

9. Suzuki S, Prihartono J, Ohno Y, Budiningsih S, Wakai K, Cornain S, et al. Epidemiologic risk factors for breast cancer related to menopausal status in Indonesia. Med J Indones 1995; 4: 169-76.

10. Cornain S. Planning, organizing and management of the collaborative project on breast cancer, Appendix E. 1995; 4: 206-11.
11. Herman S, Ohno Y, Dillon D, Cornain S, Sakamoto G, Darwis I, et al. Pilot study of food consumption pattern: Assessment of validity of dietary history method. Med J Indon 1995; 4: 183-6.

12. Dillon D, Herman S, Ohno Y, Prihartono J, Cornain S, Sakamoto G, et al. Preliminary analysis of nutritional factors in breast cancer. Med J Indon 1995; 4: 187-90.

13. Tominaga $S$, Ohno Y, editors. Introduction to epidemiology for clinicians: Focusing cancers and cardiovascular diseases. Tokyo : Nihon-Izishinposya, 1989 (in Japanese).

14. Ziegler RG. Vegetables, fruits and carotenoids and the risk of cancer. Am J Clin Nutr 1991; 53 (Suppl): 251-9.

15. Division of Nutrition, Public Health Bureau, Ministry of Health and Welfare. Prevention of cardiovascular diseases, cancers and diabetes mellitus and dietary practises - Report from Ad hoc committees for disease prevention and nutrition. Tokyo: Nihon-Eiyoshikai, 1983 (in Japanese). 